\title{
Urbanization Drives a Reduction in Functional Diversity in a Guild of Nectar-feeding Birds
}

\author{
Anton Pauw $^{1}$ and Kirsten Louw ${ }^{2}$
}

\begin{abstract}
Urbanization is a widespread and rapidly growing threat to biodiversity, therefore we need a predictive understanding of its effects on species and ecosystem processes. In this paper we study the impact of urbanization on a guild of nectar-feeding birds in a biodiversity hotspot at the Cape of Africa. The guild of four bird species provides important ecosystem services by pollinating 320 plant species in the Cape Floral Region. Functional diversity within the guild is related to differences in bill length. The long-billed Malachite Sunbird (Nectarinia famosa) plays an irreplaceable role as the exclusive pollinator of plant species with long nectar tubes. We analyzed the composition of the guild in suburban gardens of Cape Town along a gradient of increasing distance from the nearest natural habitat. Urbanization reduces the functional diversity of the nectarivore guild. Malachite Sunbirds did not penetrate more than $1 \mathrm{~km}$ into the city, whereas only the short-billed Southern Double-collared Sunbirds (Cinnyris chalybea) occurred throughout the urbanization gradient. The lack of data precludes conclusions regarding the detailed responses of Orange-breasted Sunbirds (Anthobaphes violacea) and Sugarbirds (Promerops cafer), however their absence across the entire gradient is suggestive of high sensitivity. The functional diversity of this guild of pollinators can potentially be restored, but the pros and cons of this conservation action need to be considered.
\end{abstract}

Key Words: bird pollination, citizen science, ecosystem services, hummingbird feeders, mobile link organism, mutualism disruption, nectarivore, resilience, urban ecology, urban planning

\section{INTRODUCTION}

A rapidly increasing portion of the Earth's surface is urbanized. Thus, a vast new habitat is being created and small islands of the original habitat are isolated in it (Radeloff et al. 2005, McKinney 2006, Grimm et al. 2008). Biologists often focus on the small islands of natural vegetation and ask how species diversity varies with fragment size and distance from the nearest large "mainland" of natural habitat (e.g., Bolger et al. 1997, Pauw 2007). In this paper we focus instead on the urban habitat and ask how birds respond to it.

The study is located in the hyper-diverse fynbos vegetation of the Cape Floral Region of South Africa. In it, the largest urban area is the City of Cape Town. Typical of cities in the Developing World, Cape Town is expanding rapidly and engulfing many small conservation areas and the large Table Mountain National Park (Pauw and Johnson 1999, SinclairSmith 2009). Our study group is the small guild of specialized nectarivorous birds that occur in the region. We are particularly interested in their response to urbanization because of the important ecological role that they play as pollinators of about $4 \%$ of the flora ( 320 plant species; Rebelo 1987).

Focusing conservation attention on pollinators is justified by the important ecological role that they play. Generalist pollinators, such as birds, are likely to play keystone ecological roles because, as recent network analysis shows, these species form central nodes that hold pollination webs together (Bascompte et al. 2003). Many specialist plant species depend on these generalist animal species for pollination. However, to assess whether these mutualisms matter from an ecological perspective, it is always important to ask where seed set is pollen limited and whether population growth rate is seed limited (Anderson et al. 2011, Pauw and Bond 2011).

As landscapes become increasingly heterogeneous and habitats more fragmented, mobile organisms, especially pollinators and seed dispersers, take on another increasingly important role by acting as links between separated landscape elements (Lundberg and Moberg 2003). By moving across barriers, pollinators maintain gene flow networks that can rescue small isolated plant populations from inbreeding depression.

Additionally, pollinators can contribute to the resilience of ecosystems, i.e., increase the probability that the system will return to its desirable former state following a disturbance (Folke 2006). Fires, which are often anthropogenic, are one example of such disturbances that are becoming increasingly frequent. Nectar-feeding birds could potentially enhance the ability of fynbos vegetation to return to its former desirable state by enhancing seed set in bird-pollinated plants. Especially important are the large, bird-pollinated Proteaceae and Ericaceae shrubs that depend entirely on seeds for regeneration after all the adult plants are fire-killed. These shrubs dominate many fynbos landscapes where they help to retain the soil, improve water quality, suppress alien plants, enhance tourism, provide flowers for the cut-flower industry, and enhance biodiversity (Van Wilgen 1992). 
Despite their ecologically important role, the nectarivore guild in the Cape Floral Region is surprisingly depauperate, essentially consisting of only four bird species. As a result each species performs an important function with limited overlap among guild members. This low level of functional redundancy is likely to be coupled with what might be called a low level of response diversity, meaning that it is likely that all of the species in the functional guild will respond to an environmental change, such as urbanization, in the same way (Elmqvist et al. 2003). As a result, the ecological function, in this case bird-pollination, may be entirely lost. The aim of this paper is to explore response diversity among the members of this guild. We ask: Do the different nectarivorous birds respond differently to the new urban habitat? Do some species live in it and move through it, while others perceive it as an impermeable barrier?

Surprisingly, several studies report that at least some specialized nectarivorous birds can penetrate deep into the interior of cities. In Melbourne, Australia, two species of nectarivorous lorikeets (Psittacidae) have greatly increased in abundance in the urban areas where they feed on planted Eucalyptus (Smith and Lill 2008). In Sydney, at least two species of honeyeaters (Meliphagidae) occur in urban areas where they feed on indigenous Proteaceae (French et al. 2005). Ten species of hummingbird (Trochilidae) occur in urban areas of southern Brazil where they feed mainly from exotic, insect-pollinated plants (Mendonça and dos Anjos 2005); while in Mexico City three species of hummingbirds visit Salvia species (Arizmendi et al. 2007).

More systematic surveys of birds in urban areas paint a similar picture of tolerance among some nectarivorous birds. Nectarivores were found to be more abundant in developments than in adjacent rural areas in Arizona, USA, presumably because hummingbird feeders and ornamental nectar plants made urbanized areas more attractive than the surrounding arid landscape. In New South Wales, Australia, the nectarivore guild was more likely than the insectivore guild to cross the boundary from natural into urban areas, and was more likely to cross at boundaries with high, rather than low density housing (Hodgson et al. 2007).

Gradient studies provide a detailed and predictive understanding of the ability of birds to penetrate the urban habitat. These studies explicitly test the effect of urbanization by treating "degree of urbanization" as the predictor variable and bird abundance and diversity as the response variables (Chace and Walsh 2006). One such study in California, USA, found that Anna's Hummingbird (Calypte anna) occurred across the entire gradient from conservation area through to central business district, with abundance peaking in the residential area (Blair 1996). In contrast, a study of the bird fauna of remnants of natural vegetation in California found that Costa's Hummingbird (Calypte costae) is sensitive to the fragmentation of its natural habitat by urbanization (Bolger et al. 1997). Together, the studies suggest response diversity among the members of the avian nectarivore guild when faced with urbanization, but in the latter study no surveys were conducted inside the urban matrix.

In this paper, we examine for the first time how African nectarivores respond to urbanization. To do so, we analyze the occurrence of birds in suburban gardens in relation to a gradient of increasing distance from the nearest natural habitat. The results indicate response diversity among the members of the nectarivorous bird guild, but very low permeability of urban areas by at least one functionally irreplaceable pollinator. The interesting challenge of restoring this pollination guild and the ecological services that it provides is discussed.

\section{METHODS}

\section{Study area and species}

The City of Cape Town has grown from 8000 ha to 38,000 ha since 1950 (Sinclair-Smith 2009). The natural vegetation of the area is a fire-prone shrubland, often dominated by birdpollinated Proteaceae or Ericaceae. Geophytes, primarily Iridaceae and Amaryllidaceae, provide additional nectar resources for birds. In the South Western Cape, the specialist nectarivorous guild consists of only four bird species: Cape Sugarbird (Promerops cafer), Malachite Sunbird (Nectarinia famosa), Orange-breasted Sunbird (Anthobaphes violacea), and Southern Double-collared Sunbird (Cinnyris chalybea). The species are listed in order of declining body size and bill length, a possible indicator of level of dietary specialization. Cape Sugarbirds are closely associated with the Proteaceae; Malachite Sunbirds are the exclusive pollinators of plant species with long tubular flowers mostly in the Iridaceae and Amaryllidaceae; Orange-breasted Sunbirds specialize on the Ericaceae; and Southern Double-collared Sunbirds are generalists (Skead 1967, Geerts and Pauw 2009).

\section{Bird distribution data}

Bird occurrence data were collected during 2002 and 2003 by the members of the Cape Bird Club for the Birds in Gardens Project, which was coordinated by the second author (Appendix 1). Participants recorded presence/absence checklists for 46 gardens. Each checklist spanned one day. Between 12 and 381 checklists were available for each of the 46 gardens $($ median $=139)$. Presence/absence data were converted to a "reporting rate" by dividing the number of occurrences by the number of checklists available for the particular garden. Our sample of gardens is biased toward the leafy suburbs where birdwatchers live, and this might lead to the underestimation of urbanization effects.

\section{Urbanization gradient}

Bird occurrence in gardens was related to "distance from natural vegetation." This is the same as distance into the city 
Table 1. Effect of distance from natural vegetation (natural log of $\mathrm{km}$ ) on bird reporting rate in suburban gardens analyzed by generalized linear models (error structure $=$ quasi-binomial; link function $=$ logit). Values are on the logit scale. $*=$ factors significant at the $\mathrm{p}<0.05$ level.

\begin{tabular}{|c|c|c|c|c|c|}
\hline Dependent Variable & Coefficient & Estimate & Std. Error & $\mathrm{t}$-value & $\operatorname{Pr}(>|t|)$ \\
\hline \multirow{2}{*}{$\begin{array}{l}\text { Malachite Sunbird (Nectarinia famosa) } \\
\text { reporting rate }\end{array}$} & Intercept & -3.3570 & 0.4596 & -7.303 & $<0.0001$ \\
\hline & $\begin{array}{l}\text { Distance from natural } \\
\text { vegetation }\end{array}$ & -0.8566 & 0.2213 & -3.870 & $0.0004 *$ \\
\hline \multirow{2}{*}{$\begin{array}{l}\text { Southern Double-collared Sunbird } \\
\text { (Cinnyris chalybea) reporting rate }\end{array}$} & Intercept & -0.5685 & 0.1924 & -2.954 & 0.00502 \\
\hline & $\begin{array}{l}\text { Distance from natural } \\
\text { vegetation }\end{array}$ & -0.3052 & 0.1501 & -2.033 & $0.04812 *$ \\
\hline \multirow{2}{*}{$\begin{array}{l}\text { Orange-breasted Sunbird (Anthobaphes } \\
\text { violacea) reporting rate }\end{array}$} & Intercept & -4.3433 & 0.5741 & -7.566 & $<0.0001$ \\
\hline & $\begin{array}{l}\text { Distance from natural } \\
\text { vegetation }\end{array}$ & -0.1596 & 0.3946 & -0.404 & 0.688 \\
\hline \multirow{2}{*}{$\begin{array}{l}\text { Sugarbird (Promerops cafer) reporting } \\
\text { rate }\end{array}$} & Intercept & -5.0397 & 0.5946 & -8.476 & $<0.0001$ \\
\hline & $\begin{array}{l}\text { Distance from natural } \\
\text { vegetation }\end{array}$ & -0.4656 & 0.3060 & -1.522 & 0.135 \\
\hline
\end{tabular}

from the urban edge. In all cases the nearest urban edge is a proclaimed conservation area, i.e., typically various parts of the Table Mountain National Park or the Tygerberg Nature Reserve.

\section{Statistical analyses}

The relationship between "reporting rate" and "log (distance from natural vegetation)" was analyzed separately for each of the four bird species in the statistical software R version 2.10, using generalized linear models (GLM) with a logit link function (R Development Core Team 2009). The total number of checklists for a garden was the number of "trials," and the number of checklists that reported the presence of the bird species was the number of "successes." A quasi-binomial error structure was used to account for over-dispersion of the data, which probably resulted from the nonindependence of sample days within each garden. Model prediction were backtransformed from the logit values and plotted.

\section{RESULTS}

Malachite Sunbirds and Southern Double-collared Sunbirds responded very differently to the urban habitat: Malachite Sunbirds did not penetrate more than $1 \mathrm{~km}$ into the city, whereas Southern Double-collared Sunbirds occurred throughout and showed a gradual decline in reporting rate along the urbanization gradient (Table 1, Fig. 1). The lack of data precludes clear conclusions regarding the detailed response of Orange-breasted Sunbirds and Sugarbirds to the urbanization gradient, however their absence across the entire gradient is suggestive of high sensitivity.
Fig. 1. Four species of nectar-feeding birds show differential responses to increasing urbanization. Each point is one of 46 suburban gardens located at various distances from the nearest natural vegetation. Solid lines are significant model predictions. Dashed lines are predictions from nonsignificant models. Common names are in Table 1.

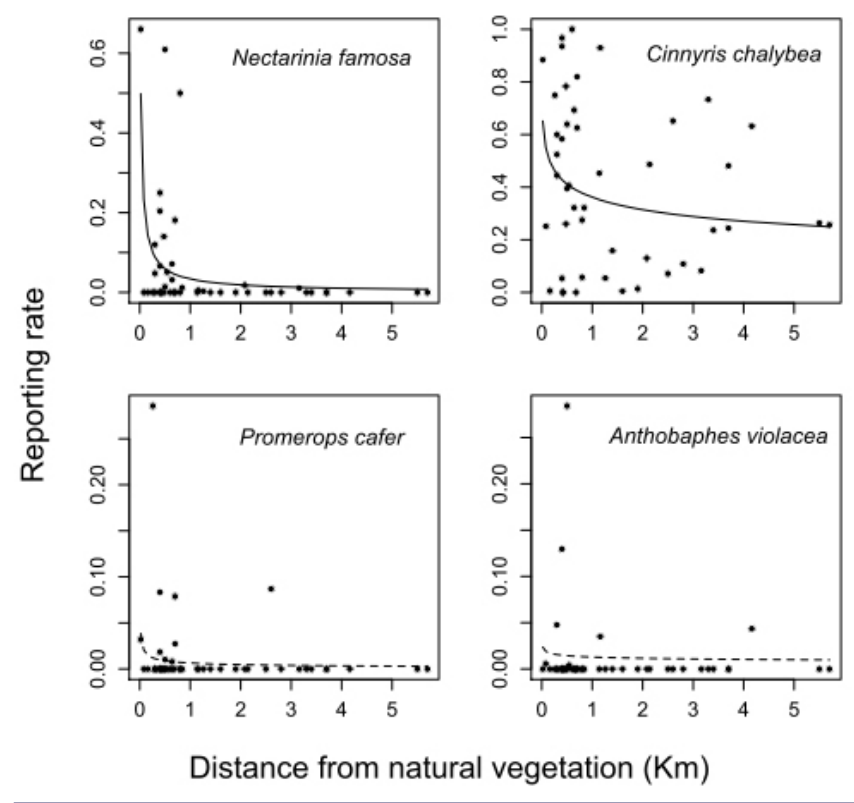




\section{DISCUSSION}

Overall, we detected a diversity of responses to urbanization among the members of the nectarivorous bird guild. With increasing distance from the nearest natural vegetation, guild diversity was reduced from four species to one. Only the generalist Southern Double-collared Sunbird occurs throughout the urbanization gradient. Sugarbirds and Orangebreasted Sunbirds apparently do not penetrate into the city at all, whereas Malachite Sunbirds only occur within $1 \mathrm{~km}$ from the nearest natural vegetation.

The strong difference in the response by Malachite Sunbirds and Southern Double-collared Sunbirds to the urbanization gradient (Table 1, Fig. 1) might result from differences in feeding ecology (Evans et al. 2011). Malachite Sunbirds have longer bills than Southern Double-collared Sunbirds (32 vs. $20.5 \mathrm{~mm}$ ) and are heavier (18 vs. 8 g; Rebelo 1987). As a result, Malachite Sunbirds tend to feed from flowers with longer tubes, and are drawn toward large nectar resources in the landscape (Geerts and Pauw 2009). Southern Doublecollared Sunbirds can exploit both short and long-tubed flowers, the latter by puncturing the corolla, and can utilize small nectar resources. It seems likely then that the urban habitat provides sufficient nectar for Southern Doublecollared Sunbirds, but not for Malachite Sunbirds. The sudden drop-off in the reporting rate of Malachite Sunbirds at distances greater than $1 \mathrm{~km}$ from the nearest natural vegetation suggests that individuals along the perimeter of the city are dependent on resources in nearby natural areas. The contrast sketched here suggests a global analysis of the relationship between nectarivore traits, e.g., bill length and weight, and responses to urbanization. Previous studies on plants (Williams et al. 2009), beetles (Sadler et al. 2006), birds (Carrete and Tella 2011, Evans et al. 2011), and bees (Cane et al. 2006, Ahrné et al. 2009) have been successful in identifying traits that predict responses to urbanization.

The lack of data precludes a detailed understanding of the response of Orange-breasted Sunbirds and Sugarbirds to the urbanization gradient (Fig. 1, Table 1). Ideally, this study should have included surveys in natural habitat. Such surveys, recorded in The Atlas of Southern African Birds, indicate that both Sugarbirds and Orange-breasted Sunbirds occur at frequencies similar to those of Malachite Sunbirds and Southern Double-collared Sunbirds in natural habitat adjoining the urban areas (Harrison et al. 1997). Hence, we interpret the consistently low reporting rates for the urban area as a preliminarily indication of very high sensitivity to urbanization. Sugarbirds (37 g) are twice as heavy as Malachite Sunbirds and their consequentially larger nectar requirements could explain their absence from urban areas. The same is not true for Orange-breasted Sunbirds (10 g, bill length $21 \mathrm{~mm}$ ), and their absence from urban areas begs explanation. Our earlier work shows that Orange-breasted Sunbirds are sensitive to road traffic (Geerts and Pauw 2011), while other studies suggest that fear of humans and vehicles is an important trait that predicts bird responses to urbanization (Carrete and Tella 2011).

How is the observed reduction in bird diversity due to urbanization likely to affect pollination? Lesser Doublecollared Sunbirds might to an extent be able to replace the lost services provided by Orange-breasted Sunbirds, which have similar bill lengths, and can play a role in pollinating certain Proteaceae species in the absence of Sugarbirds. These plant species that are pollinated by more than one bird species will benefit from the functional redundancy in the guild and the diversity of responses among guild members in the face of disturbance. However, there is limited functional redundancy in the guild. In particular, the demonstrated sensitivity of Malachite Sunbirds to urbanization is of concern because of the functionally irreplaceable role that this species plays as the exclusive pollinator of plant species with floral tubes in excess of $35 \mathrm{~mm}$ (Geerts and Pauw 2009). The endangered Brunsvigia litoralis serves as an example. Populations that occur in small fragmented populations, which lack Malachite Sunbirds, suffer reduced seeds set because of severe pollen limitation and experience high rates of nectar robbing by short-billed sunbirds, which pierce holes through the side of the flower to access the nectar. Only Malachite Sunbirds with their longer bills visit the flowers legitimately and transfer pollen (Geerts and Pauw 2012). The loss of this bird species clearly precipitates a loss in functional diversity (Lindberg and Olesen 2001, Petchey and Gaston 2006).

The questions to answer now are: Do we want to restore the nectarivorous bird guild in cities, and how? The restoration of pollination in cities will help to repair broken mutualism and rescue plant populations in urban conservation areas (Pauw and Hawkins 2010, Anderson et al. 2011, Pauw and Bond 2011). For example, Malachite Sunbirds historically occurred at Rondevlei Nature Reserve located inside the city, but are currently absent with implications for long-tubed plant species such as Brunsvigia orientalis that occur there (Pauw 2004). Although the nectarivore guild is still intact in the Table Mountain National Park, this extensive conservation area is entirely cut off from other natural areas by the interposition of the City of Cape Town. The opportunity for the creation of continuous green corridors to link these islands no longer exists, but it is possible to make the urban matrix more permeable to nectarivores in an attempt to restore metapopulation dynamics (Colding 2007, Lundberg et al. 2008, Tremblay and St. Clair 2011). The dynamics of local emigration and immigration are likely to be particularly important in fire-prone vegetation, such as fynbos, where nectar availability fluctuates on a 6 to 20 year fire cycle (Pauw 2004, Geerts et al. 2012).

If the distribution of the nectarivorous birds is limited by nectar availability, then restoration is certainly possible by (1) 
installing bird-feeders in the city, and (2) planting appropriate nectar plants. Potentially, both approaches could be implemented through the schools network and linked to the school curriculum, but the practicalities will have to be thrashed out during workshop sessions. Bird feeders are easy to construct from recycled materials, can be filled with a sugar in water solution, and can be designed to be accessible only by long-billed species. The latter is a physics and chemistry lesson in itself with scope for learning about air-pressure, solutions, and concentrations. However, nectar feeders need to be serviced regularly, so have limited utility for long-term restoration.

The planting of nectar plants in school gardens is likely to have a longer term impact and will bring many additional advantages such as noise pollution reduction and psychological health and well-being (Armstrong 2000, Goddard et al. 2010, Fontana et al. 2011, Lerman and Warren 2011). Schools can be selected to form a series of steppingstones linking important conservation areas to the nearest natural vegetation (Colding 2007, Tremblay and St. Clair 2011). Plant species will have to be selected based on flowering phenology to provide a yearlong supply of nectar. Learners can easily identify the small number of nectarfeeding birds and report observations via a web-linked cell phone application or electronic social networks, e.g., Twitter. com, MXit.com. Data can be uploaded onto databases such as the citizen science driven Southern African Bird Atlas Project (http://mybirdpatch.adu.org.za), from where the restoration attempt can be monitored.

A project such as this will help to build a meaningful link between urban conservation areas and the surrounding communities, and will be a good test case for conservation action beyond reserve boundaries. Birds can serve as flagships for a broader pollinator restoration project, and pollinator gardens can provide forage for other important pollinators such as bees, which are also impacted by urbanization (Cane et al. 2006, Pauw 2007, Ahrné et al. 2009).

In deciding whether or not to restore the nectar-feeding bird guild, possible negative ecological consequences of restoration should be considered. The first concern is contamination of wild plant populations by genes from horticultural varieties when birds move pollen between urban and natural areas. Horticultural varieties are selected for traits, such as prolonged flowering, that are likely to be maladaptive in a natural setting. The problem of contamination can potentially be overcome if seed is harvested from local seed sources. Second, feeders and garden plants might attract birds away from wild plant populations (Arizmendi et al. 2007), although studies of hummingbirds suggest that birds prefer to visit flowers rather than hummingbird feeders (Inouye et al. 1991, McCaffrey and Wethington 2008). Last, feeders might facilitate the spread of disease among birds, although there is little evidence for this (Saidenberg et al. 2007).
Responses to this article can be read online at: http://www.ecologyandsociety.org/voll7/iss2/art27/ responses/

\section{Acknowledgments:}

This paper is a product of the Urban Ecology CityLab which is part of the CityLab programme of the African Centre for Cities at the University of Cape Town. The African Centre for Cities' CityLab programme is funded through the Mistra Urban Futures network (which is funded by Mistra the Foundation for Strategic Environmental Research and the Swedish International Development Cooperation Agency), the Provincial Government of the Western Cape (Department of Human Settlements), and the City of Cape Town. We would like to thank all the citizens who participated in the Birds in Gardens Project, Jan Bengtsson, Carl Folke and one anonymous reviewer for useful input.

\section{LITERATURE CITED}

Ahrné, K., J. Bengtsson, and T. Elmqvist. 2009. Bumble bees (Bombus spp) along a gradient of increasing urbanization. PLOS ONE 4:e5574. http://dx.doi.org/10.1371/journal.pone.0 005574

Anderson, S. H., D. Kelly, J. J. Ladley, S. Molloy, and J. Terry. 2011. Cascading effects of bird functional extinction reduce pollination and plant density. Science 331:1068-1071. http://d x.doi.org/10.1126/science.1199092

Arizmendi, M. D., M. S. Constanza, J. Lourdes, F. M. Ivonne, and L. S. Edgar. 2007. Effect of the presence of nectar feeders on the breeding success of Salvia mexicana and Salvia fulgens in a suburban park near Mexico City. Biological Conservation 136:155-158. http://dx.doi.org/10.1016/j.biocon.2006.11.016

Armstrong, D. 2000. A survey of community gardens in upstate New York: implications for health promotion and community development. Health and Place 6:319-327. http:/ /dx.doi.org/10.1016/S1353-8292(00)00013-7

Bascompte, J., P. Jordano, C. J. Melián, and J. M. Olesen. 2003. The nested assembly of plant-animal mutualistic networks. Proceedings of the National Academy of Sciences of the United States of America 100:9383-9387. http://dx.doi. org/10.1073/pnas.1633576100

Blair, R. B. 1996. Land use and avian species diversity along an urban gradient. Ecological Applications 6:506-519. http:// dx.doi.org/10.2307/2269387

Bolger, D. T., T. A. Scott, and J. T. Rotenberry. 1997. Breeding bird abundance in an urbanizing landscape in coastal southern California. Conservation Biology 11:406-421. http://dx.doi.o $\mathrm{rg} / 10.1046 / \mathrm{j} .1523-1739.1997 .96307 . \mathrm{x}$ 
Cane, J. H., R. L. Minckley, L. J. Kervin, T. H. Roulston, and N. M. Williams. 2006. Complex responses within a desert bee guild (Hymenoptera: Apiformes) to urban habitat fragmentation. Ecological Applications 16:632-644. http://dx. doi.org/10.1890/1051-0761(2006)016[0632:CRWADB]2.0.CO;2

Carrete, M., and J. L. Tella. 2011. Inter-individual variability in fear of humans and relative brain size of the species are related to contemporary urban invasion in birds. PLOS ONE 6:e18859. http://dx.doi.org/10.1371/journal.pone.0018859

Chace, J. F., and J. J. Walsh. 2006. Urban effects on native avifauna: a review. Landscape and Urban Planning 74:46-69. http://dx.doi.org/10.1016/j.landurbplan.2004.08.007

Colding, J. 2007. 'Ecological land-use complementation' for building resilience in urban ecosystems. Landscape and Urban Planning 81:46-55. http://dx.doi.org/10.1016/j.landurb plan.2006.10.016

Elmqvist, T., C. Folke, M. Nyström, G. Peterson, J. Bengtsson, B. Walker, and J. Norberg 2003. Response diversity, ecosystem change, and resilience. Frontiers in Ecology and the Environment 1:488-494. http://dx.doi.org/10.1890/1540-9295 (2003)001[0488:RDECAR]2.0.CO;2

Evans, K. L., D. E. Chamberlain, B. J. Hatchwell, R. D. Gregory, and K. J. Gaston. 2011. What makes an urban bird? Global Change Biology 17:32-44. http://dx.doi.org/10.1111/j .1365-2486.2010.02247.x

Folke, C. 2006. Resilience: the emergence of a perspective for social-ecological systems analyses. Global Environmental Change 16:253-267. http://dx.doi.org/10.1016/j.gloenvcha.20 $\underline{06.04 .002}$

Fontana, S., T. Sattler, F. Bontadina, and M. Moretti. 2011. How to manage the urban green to improve bird diversity and community structure. Landscape and Urban Planning 101:278-285. http://dx.doi.org/10.1016/j.landurbplan.2011.02.033

French, K., R. Major, and K. Hely. 2005. Use of native and exotic garden plants by suburban nectarivorous birds. Biological Conservation 121:545-559. http://dx.doi.org/10.10 16/j.biocon.2004.06.004

Geerts, S., S. D. T. Malherbe, and A. Pauw. 2012. Reduced flower visitation by nectar-feeding birds in response to fire in Cape fynbos vegetation, South Africa. Journal of Ornithology 153:297-301. http://dx.doi.org/10.1007/s10336-011-0743-9

Geerts, S., and A. Pauw. 2009. Hyper-specialization for longbilled bird pollination in a guild of South African plants: the Malachite Sunbird pollination syndrome. South African Journal of Botany 75:699-706. http://dx.doi.org/10.1016/j.saj $\underline{\text { b.2009.08.001 }}$
Geerts, S., and A. Pauw. 2011. Easy technique for assessing pollination rates in the genus Erica reveals road impact on bird pollination in the Cape fynbos, South Africa. Austral Ecology 36:656-662. http://dx.doi.org/10.1111/j.1442-9993.2010.02201. $\underline{\mathrm{x}}$

Geerts, S., and A. Pauw. 2012. The cost of being specialized: pollinator limitation in the endangered geophyte Brunsvigia litoralis (Amaryllidaceae) in the Cape Floristic Region of South Africa. South African Journal of Botany 78:159-164. http://dx.doi.org/10.1016/j.sajb.2011.06.007

Goddard, M. A., A. J. Dougill, and T. G. Benton. 2010. Scaling up from gardens: biodiversity conservation in urban environments. Trends in Ecology \& Evolution 25:90-98. http: //dx.doi.org/10.1016/j.tree.2009.07.016

Grimm, N. B., S. H. Faeth, N. E. Golubiewski, C. L. Redman, J. Wu, X. Bai, and J. M. Briggs. 2008. Global change and the ecology of cities. Science 319:756-760. http://dx.doi.org/10.1 $\underline{126 / \text { science. } 1150195}$

Harrison, J. A., D. G. Allan, L. G. Underhill, M. Herremans, A. J. Tree, V. Parker, and C. J. Brown, editors. 1997. The atlas of southern African birds. BirdLife South Africa, Johannesburg, South Africa.

Hodgson, P., K. French, and R. E. Major. 2007. Avian movement across abrupt ecological edges: differential responses to housing density in an urban matrix. Landscape and Urban Planning 79:266-272. http://dx.doi.org/10.1016/j. landurbplan.2006.02.012

Inouye, D. W., W. A. Calder, and N. M. Waser. 1991. The effect of floral abundance on feeder censuses of hummingbird populations. Condor 93:279-285. http://dx.doi.org/10.2307/1 $\underline{368943}$

Lerman, S. B., and P. S. Warren. 2011. The conservation value of residential yards: linking birds and people. Ecological Applications 21:1327-1339. http://dx.doi.org/10.1890/10-0423.1

Lindberg, A. B., and J. M. Olesen. 2001. The fragility of extreme specialization: Passiflora mixta and its pollinating hummingbird Ensifera ensifera. Journal of Tropical Ecology 17:323-329. http://dx.doi.org/10.1017/S0266467401001213

Lundberg, J., E. Andersson, G. Cleary, and T. Elmqvist. 2008. Linkages beyond borders: targeting spatial processes in fragmented urban landscapes. Landscape Ecology 23:717-726. http://dx.doi.org/10.1007/s10980-008-9232-9

Lundberg, J., and F. Moberg. 2003. Mobile link organisms and ecosystem functioning: implications for ecosystem resilience and management. Ecosystems 6:0087-0098. http:// dx.doi.org/10.1007/s10021-002-0150-4 
McCaffrey, R. E., and S. M. Wethington. 2008. How the presence of feeders affects the use of local floral resources by hummingbirds: a case study from southern Arizona. Condor 110:786-791. http://dx.doi.org/10.1525/cond.2008.8621

McKinney, M. L. 2006. Urbanization as a major cause of biotic homogenization. Biological Conservation 127:247-260. http: //dx.doi.org/10.1016/j.biocon.2005.09.005

Mendonça, L. B., and L. dos Anjos. 2005. Beija-flores (Aves, Trochilidae) e seus recursos florais em uma área urbana do Sul do Brasil. [Hummingbirds (Aves, Trochilidae) and their flowers in an urban area of southern Brazil]. Revista Brasileira De Zoologia 22:51-59. http://dx.doi.org/10.1590/S0101-8175 $\underline{2005000100007}$

Pauw, A. 2004. Variation in pollination across a fragmented landscape at the Cape of Africa. Dissertation, University of Cape Town, Cape Town, South Africa.

Pauw, A. 2007. Collapse of a pollination web in small conservation areas. Ecology 88:1759-1769. http://dx.doi.org/ $\underline{10.1890 / 06-1383.1}$

Pauw, A., and W. J. Bond. 2011. Mutualisms matter: pollination rate limits the distribution of oil-secreting orchids. Oikos 120:1531-1538. http://dx.doi.org/10.1111/j.1600-0706 .2011.19417.x

Pauw, A., and J. A. Hawkins. 2010. Reconstruction of historical pollination rates reveals linked declines of pollinators and plants. Oikos 120:344-349. http://dx.doi.org/1 0.1111/j.1600-0706.2010.19039.x

Pauw, A., and S. D. Johnson. 1999. Table Mountain: a natural history. Fernwood Press, Cape Town, South Africa.

Petchey, O. L., and K. J. Gaston. 2006. Functional diversity: back to basics and looking forward. Ecology Letters 9:741-758. http://dx.doi.org/10.1111/j.1461-0248.2006.00924. $\underline{\mathrm{X}}$

$\mathrm{R}$ Development Core Team. 2009. R: A language and environment for statistical computing. $\mathrm{R}$ Foundation for Statistical Computing, Vienna, Austria.

Radeloff, V. C., R. B. Hammer, S. I. Stewart, J. S. Fried, S. S. Holcomb, and J. F. McKeefry. 2005. The wildland-urban interface in the United States. Ecological Applications 15:799-805. http://dx.doi.org/10.1890/04-1413

Rebelo, A. G. 1987. Bird pollination in the Cape Flora. Pages 83-108 in A. G. Rebelo, editor. A preliminary synthesis of pollination biology in the Cape flora. CSIR, Pretoria, South Africa.

Sadler, J. P., E. C. Small, H. Fiszpan, M. G. Telfer, and J. Niemelä. 2006. Investigating environmental variation and landscape characteristics of an urban-rural gradient using woodland carabid assemblages. Journal of Biogeography
33:1126-1138. http://dx.doi.org/10.1111/j.1365-2699.2006.01476. $\underline{\mathrm{x}}$

Saidenberg, A. B. S., R. H. F. Teixeira, C. S. Astolfi-Ferreira, T. Knöbl, and A. J. P. Ferreira. 2007. Serratia marcescens infection in a Swallow-tailed Hummingbird. Journal of Wildlife Diseases 43:107-110.

Sinclair-Smith, K. 2009. The expansion of urban Cape Town. Metropolitan Spatial Planning Branch, Spatial Planning \& Urban Design Department, City of Cape Town, South Africa.

Skead, C. J. 1967. The sunbirds of southern Africa, also the Sugarbirds, the White-eyes and the Spotted Creeper. Balkema for the Trustees of the South African Bird Book Fund, Cape Town, South Africa.

Smith, J., and A. Lill. 2008. Importance of eucalypts in exploitation of urban parks by Rainbow and Musk Lorikeets. Ети 108:187-195. http://dx.doi.org/10.1071/MU07062

Tremblay, M. A., and C. C. St. Clair. 2011. Permeability of a heterogeneous urban landscape to the movements of forest songbirds. Journal of Applied Ecology 48:679-688. http://dx. doi.org/10.1111/j.1365-2664.2011.01978.x

Van Wilgen, B. W., D. M. Richardson, F. J. Kruger, and H. J. van Hensbergen, editor. 1992. Fire in South African mountain fynbos: species, community and ecosystem response in Swartboskloof. Springer Verlag, Heidelberg, Germany.

Williams, N. S. G., M. W. Schwartz, P. A. Vesk, M. A. McCarthy, A. K. Hahs, S. E. Clemants, R. T. Corlett, R. P. Duncan, B. A. Norton, K. Thompson, and M. J. McDonnell. 2009. A conceptual framework for predicting the effects of urban environments on floras. Journal of Ecology 97:4-9. htt p://dx.doi.org/10.1111/j.1365-2745.2008.01460.x 
Appendix 1

Number of days on which nectar feeding birds were observed in urban gardens located at various distances from the nearest natural vegetation.

\begin{tabular}{|c|c|c|c|c|c|c|c|c|}
\hline Surname & Name & Suburb & Promerops_cafer & Nectarinia_famosa & Anthobaphes_violacea & Cinnyris_chalybea & Total_days & $\mathrm{Km}$ \\
\hline New & Judy & Paarl & 8 & 165 & 0 & 221 & 250 & 0.02 \\
\hline Russell & GM & Fresnaye & 0 & 0 & 2 & 89 & 354 & 0.08 \\
\hline Hill_H & Candace & Lakeside & 0 & 0 & 0 & 1 & 164 & 0.16 \\
\hline Herman & Brian & Lakeside & 16 & 0 & 0 & 42 & 56 & 0.26 \\
\hline Johnson & Jo & FishHoek & 0 & 3 & 0 & 15 & 25 & 0.3 \\
\hline McAdam & Anne & FishHoek & 0 & 1 & 1 & 11 & 21 & 0.3 \\
\hline Gordon & Lynne & Noordhoek & 0 & 0 & 0 & 12 & 27 & 0.3 \\
\hline Dallas & Evan & Bloubergstrand & 0 & 0 & 0 & 6 & 113 & 0.4 \\
\hline Berg & Brigitte & Constantia & 2 & 22 & 14 & 101 & 108 & 0.4 \\
\hline Oosthuizen & Edith & Somerset & 1 & 3 & 0 & 7 & 12 & 0.4 \\
\hline Morris & SA & Tokai & 0 & 6 & 0 & 88 & 91 & 0.4 \\
\hline WynneDyke & Ken_Vygeboom & Durbanville & 0 & 0 & 0 & 0 & 111 & 0.42 \\
\hline $\mathrm{Nel}$ & Theo & Milnerton & 0 & 0 & 0 & 0 & 61 & 0.42 \\
\hline Metcalf & Marilyn & Kommetjie & 0 & 22 & 0 & 123 & 157 & 0.48 \\
\hline Vogel & $x$ & Welgemoed & 0 & 0 & 0 & 50 & 192 & 0.48 \\
\hline Hobbs & Jo & Brackenfell & 0 & 2 & 0 & 58 & 147 & 0.5 \\
\hline Rebelo & A & Durbanville & 2 & 120 & 56 & 126 & 197 & 0.5 \\
\hline DeVilliers & M_Dbnville & Durbanville & 0 & 13 & 1 & 103 & 254 & 0.54 \\
\hline Durrant & Rose & Constantia & 0 & 0 & 0 & 36 & 36 & 0.6 \\
\hline Moll_P & Mike & Paarl & 0 & 2 & 0 & 9 & 28 & 0.64 \\
\hline Weiss & Yvonne & Paarl & 3 & 12 & 0 & 264 & 381 & 0.64 \\
\hline WynneDyke & Ken_Sonstraal & Durbanville & 0 & 0 & 0 & 0 & 215 & 0.68 \\
\hline Ellis & Robert & Durbanville & 20 & 46 & 0 & 159 & 254 & 0.7 \\
\hline Copeland & Paarl & Paarl & 5 & 0 & 0 & 150 & 183 & 0.7 \\
\hline Maciver & Margaret & Milnerton & 0 & 26 & 0 & 3 & 52 & 0.8 \\
\hline Ross & Virginia & Newlands & 0 & 0 & 0 & 36 & 131 & 0.8 \\
\hline Wordon & Daphne & Durbanville & 0 & 2 & 0 & 53 & 165 & 0.84 \\
\hline Viljoen & Maureen & Constantia & 0 & 0 & 0 & 96 & 212 & 1.14 \\
\hline Louw & Kirsten & Constantia & 0 & 1 & 7 & 186 & 200 & 1.16 \\
\hline WynneDyke & Ken_Hebron & Durbanville & 0 & 1 & 0 & 18 & 330 & 1.26 \\
\hline Booth & Joan & Constantia & 0 & 0 & 0 & 13 & 82 & 1.4 \\
\hline Barnes_H & Dick & Rondebosch & 0 & 0 & 0 & 1 & 205 & 1.6 \\
\hline Burger & Lou & Rondebosch & 0 & 0 & 0 & 1 & 74 & 1.9 \\
\hline Lockhart & Pat & Constantia & 0 & 3 & 0 & 22 & 169 & 2.08 \\
\hline VanderVliet & Virginia & Rondebosch & 0 & 0 & 0 & 18 & 37 & 2.14 \\
\hline Beighton & Peter & Rondebosch & 0 & 0 & 0 & 17 & 238 & 2.5 \\
\hline Nupen & Peter & Parow & 2 & 0 & 0 & 15 & 23 & 2.6 \\
\hline Jones & Fiona & Claremont & 0 & 0 & 0 & 12 & 111 & 2.8 \\
\hline Ledgard & Sylvia & Edgemead & 0 & 4 & 0 & 31 & 375 & 3.16 \\
\hline Crosswell & Judith & Kenilworth & 0 & 0 & 0 & 22 & 30 & 3.3 \\
\hline Koeslag2 & Ann & Plumstead & 0 & 0 & 0 & 31 & 131 & 3.4 \\
\hline Adam & Sally & Plumstead & 0 & 0 & 0 & 51 & 209 & 3.7 \\
\hline Joubert & Audrey & Wynberg & 0 & 0 & 0 & 26 & 54 & 3.7 \\
\hline Eva & Jean & Kenilworth & 0 & 0 & 13 & 189 & 299 & 4.16 \\
\hline Kerr & Libby & Parow & 0 & 0 & 0 & 24 & 91 & 5.5 \\
\hline Anderson & Brenda & Pinelands & 0 & 0 & 0 & 95 & 371 & 5.7 \\
\hline
\end{tabular}

